\title{
Congolese Literature as Part of Planetary Literature
}

\author{
Silvia Riva | ORCID: 0000-0002-0100-0569 \\ Università degli Studi di Milano, Milan, Italy \\ silvia.riva@unimi.it
}

\begin{abstract}
Historically and economically, the Congo has been considered one of the most internationalized states of Africa. The idea that African cultural plurality was minimized during the colonial era has to be reconsidered because textual negotiations and exchanges (cosmopolitan and vernacular, written and oral) have been frequent during and after colonization, mostly in urban areas. Through multilingual examples, this paper aims to question the co-construction of linguistic and literary pluralism in Congo and to advocate for the necessity of a transdisciplinary and collaborative approach, to understand the common life of African vernacular and cosmopolitan languages. I show that world literature models based on Pierre Bourdieu's notion of negotiation between center and periphery thus have to be replaced by a concept of multilingual global history. Finally, I propose the notion of "planetary literature" as a new way of understanding the interconnection between literatures taking care of the world.
\end{abstract}

\section{Keywords}

restitution - post-scriptural orality - planetary literature - multilingualism - Third Landscape

Let me start by recalling an essay dating back to the early 199os by the philosopher V.Y. Mudimbe. In relation to contemporary African art, he introduced the notion of reprendre (literally, "to retake") to mean both the act of

taking up an interrupted tradition, not out of a desire for purity, which would testify only to the imaginations of dead ancestors, but in a way 
that reflects the conditions of today, [and] a methodical assessment, the artist's labour beginning, in effect, with the evaluation of the tools, means, and projects of art within a social context transformed by colonialism and by later currents, influences and fashions from abroad.

"Reprendre" 276

This notion of reprendre, of recasting an interrupted tradition, led him to a meditation about how to reconsider both the meaning of African traditional artifacts and their inscription in the Western archive.

Almost forty years later, in the field of contemporary African arts, one answer to this meditation has been the concept of restitution: first, in terms of the practical restitution of the traditional heritage kept in Western ethnological and art museums, but also in a metaphorical sense. This means using the colonial archive (documents, objects, drawings, masks) as a palimpsest to rewrite history from the point of view of African needs today, while being aware that the colonial paradigm cannot be ignored because it is now part of our global, common history. One thing is certain: the "'radical reconversion of African arts' undertaken 'in the colonial settings' has neither generated a clear-cut withdrawal from the past, nor produced a neat and regimented reordering and assimilation of aesthetic practices" (Fraiture 226, quoting Mudimbe Idea 156). If we abandon for a moment considerations relating to the world of the arts and place ourselves in a literary perspective, the prospect of a different narrative or discourse about the African (in our case, mostly Francophone) emergence of literature can only be realized by starting from a rereading of the past - not as an interrupted continuity (to be resumed or restored in its integrity through restitution), but as a subterranean continuity that has never been interrupted, and which can be grasped through a broader vision than the continental one (in precolonial terms) or the imperial one (colonial or postcolonial), embracing multilingualism and overcoming the compartmentalization of oral and written texts. This broader perspective, which I would call "planetary," allows us to grasp not only the global interconnection of phenomena - Édouard Glissant already coined, in the 199os, the concept of "Tout-monde" and "archipelagic thinking" referring, however, to issues of cultural identity ${ }^{1}$ - but also the agency

1 Glissant's concept of "Tout-monde," closely related to "archipelagic" thought and elaborated in a synthetic way in his Introduction à une poétique du divers (1996), is still of pressing relevance today in considering the phenomena of interconnection, often not immediately visible, which, in the long term and according to a dynamic approach, concern all cultural phenomena. Any culture that considers itself rooted and "pure" does not take into account the fact that it was itself, in more or less ancient times, the result of "créolisation" (a new sort of hybridiza- 
that an all-encompassing vision could entail. As Achille Mbembe and Felwine Sarr underlined in the 2019 edition of the Ateliers de la Pensée de Dakar, "there is an urgent need for languages, experiences and thoughts making people able to think about themselves through each other."2 This rethinking is crucial for (re)inventing the "en-commun" (Seck 309), the common ground on which lies the ever endangered protection of our planet. I will return to this idea in the final part of the essay.

In this spirit, let me share a few questions about African, and particularly Congolese, literatures by thinking through the concepts of recasting, restitution, and the idea of "thinking through each other" in pursuit of common ground. Before developing these questions, however, it might be necessary to recall the old adage that the battle for the affirmation of the French language was played out in print. As Bernard Mouralis writes in an article on the colonial period, "the situation in which African writers have found themselves in relation to oral literature [makes it possible] to specify a particular context, marked precisely by the constant interference between cultural and political dimensions, between African legitimacy and colonial legitimacy, knowledge and institutions" (216)..$^{3}$ In this respect, the study of the relationship of the colonial institution to oral production shows a certain selectivity, which focuses rather on the conte (tale), considered the expression of a traditional and timeless culture, and tends to discard texts referring to the tensions and conflicts born out of the colonial situation, such as, for example, the epics (in the Congolese context, we can think of kasala, ${ }^{4}$ a Tshiluba epic poem with a rich ritual

tion which results in an unexpected surplus that exceeds the simple sum of the cultural heritage of the parties that meet). In accordance with the theoretical concerns of the period in which the essay was written, Glissant's vision has its focus on the question of identity, which has been the battleground of the postcolonial era. In this article, on the contrary, according to a decolonial epistemological perspective (which takes into account the multiplicity of situated epistemologies in the world), my intention is to avoid any polarization in the name of a polycentricity of phenomena on a planetary scale (not only global, which invites precisely the vision of the constant negotiation between two antagonist poles: centre and peripheries).

2 "Il est urgent que langues, expériences et pensées puissent (se) penser les unes à travers les autres." (Les Ateliers de la pensée)

3 "La situation dans laquelle se sont trouvés placés les écrivains africains par rapport aux littératures orales [permet] de préciser un contexte particulier, marqué notamment par une interférence constante entre dimension culturelle et dimension politique, entre légitimité africaine et légitimité coloniale, connaissance et institution." My translation.

4 A kasala is a poem of praise from the Luba tradition (a community rooted mainly in the East Kasai and Upemba region of the Democratic Republic of Congo). Sung to oneself, a relative, a dignitary, or even a fictional character, this oral poem is still alive and has very recently been updated for artistic purposes in the performance Abattoir des rêves ou la faute à Bende, l'Aîné 
and political dimension). One of the most serious researchers in the field of African orality, Hans-Jürgen Lüsebrink, defines this colonial reading as "dehistoricization" (78).

With this caveat in mind and with regard to the concept of reprendre in literature, one may ask the following: Did the transcription of African languages carried out at the beginning of colonization mostly by religious institutions really interrupt the "natural evolution" of these languages by imposing the assimilationist model in French-speaking areas? If not (or, rather, if not com-

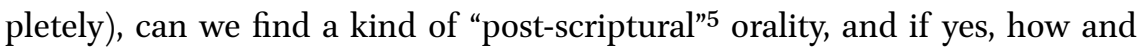
where? Second, with regard to restitution, what does it mean in literary terms? And what is the relation of these two terms with world literature models? A first answer could be suggested by the notion of "reading together," ${ }^{\prime \prime}$ because African discourses and literatures (in imperial or African languages) can be interpreted as the "continuation of a long [colonial] discontinuity that dates back to the classical age and which, for nearly a century now, seems to have definitively initiated the transfiguration of [Western] epistemology" (Mangeon $868)^{7}$ into something shared by many. Restitution means, in a way, imagining a new literary history for the Congo (and Africa, but also for the rest of the world) that is open to plural comparisons stemming from localities that are situated in linguistic, cultural, and literary terms (between North and South, South and North, but also between Souths ${ }^{8}$ ). This new way of reading literature is multilingual and global, without being necessarily globalized (that is to say, influenced by market play, strategic patterns, and former imperial consecra-

des Hommes, d'avoir boycotté la création? (Abattoir of Dreams or the fault of Bende, the Elder of Men, for boycotting the creation?) which took place at Villa Medici, Rome, in January 2020 (text: Fiston Mwanza Mujila; artistic creation: Sammy Baloji).

5 For this concept, see Jewsiewicki. I will return to this concept later.

6 See Francesca Orsini's paper "Reading Together: Hindi, Urdu, and English Village Novels," in which she states: "How to do a multilingual history of the novel, and why should we even attempt such an enterprise? In her essay 'The aesthetics and politics of 'reading together'. Moroccan novels in Arabic and French,' Karima Laachir lays out the reasons for such an enterprise in the context of Morocco, and several of her arguments are pertinent to North India, too" (Ciocca and Srivastava 61).

7 I am quoting Anthony Mangeon with some omissions and important changes: "on peut interpréter le discours noir comme la continuation la plus effective d' une longue discontinuité qui remonte à l'âge classique et qui, depuis près d'un siècle à présent, nous semble avoir définitivement engagé la transfiguration de l'épistémè métisse."

8 From this point of view, we can think about the problematic category of the "Global South" with regard to French-speaking Congolese literature: new connections have recently been made with the Caribbean space, and more precisely, with Cuba (see Elisabeth MudimbeBoyi). At the literary level, we can think of the connections between the DRC and the Lusophone space through Angola (see the recent novel by Fiston Mwanza Mujila 2020). 
tions and circuits). This particular approach allows us to consider the Congo, due to its historically situated internationalism, as a literary locus that is by nature both center and periphery, or that collapses the colonial polarity into a center without a periphery, if you will. As literary site, the Congo is representative of other such apolar constituencies across the globe. I will return to this subject in detail in the last section.

Finally, I will present the idea of planetary literature as a possible evolution of a certain idea of world literature. Considering the world as a planet means, to me, to get out of the logic of the book marketplace and its agency and to take responsibility for future generations and non-human species - not only because, as Amitav Ghosh has illustrated in The Great Derangement, climate change is no longer an extraordinary object of some post-apocalyptic literature, but also because the planetary dimension (the metaphorical myth of world as unity) is inherent, after all, in any work of literature, at any latitude. The ground is common, and so is the planet.

\section{Linguistic Pluralism and the Contemporary Return of the Precolonial and Colonial Cultural Past}

The Congo is, like many other African countries, an example of linguistic pluralism despite the centralization of the (Belgian) colonial regime. The DRC is indeed the most populated French-speaking country in the world after France, and in 2018, 42 million Congolese, or $5^{1}$ percent of the country's population, were able to read and write French ("Observatoire de la langue"). The case of the Congo is particularly interesting because it is also one of the most internationalized nations in Africa (historically and economically speaking): King Leopold II of Belgium managed to carve out an empire by cunningly negotiating with more powerful colonial powers, guaranteeing that all nations could exercise free trade in his territory. King Leopold's "Free State" (1885-1908) lasted well beyond 1908, when it became the Belgian Congo and, economically, well beyond 196o, the year of Congolese independence. This internationalization is so intrinsic to Congolese history that one of the best-known contemporary Congolese novels bears the title Congo Inc. and the subtitle Bismarck's Testament (Bofane 2018) so as to underline how the ferocity of today's corporatization and the exploitation of Congo's rich soil are the results of decisions taken at the Berlin Conference of $1884-85$.

Furthermore, the case of the Congo is interesting because it shows that even if there were violent attempts of acculturation during the colonial period ("dehistoricization" and critiques of cultural pluralism), monolingual rule has to 
be rethought. Negotiations and exchanges between texts and languages (both traditionally cosmopolitan and local) have always been frequent - in both directions. ${ }^{9}$ Let me give a few examples taken respectively from the visual arts, music, and literature. The entanglement of "Congolese"10 languages (altogether more than two hundred, with four official ones: Kikongo, Tshiluba, Lingala, and Kiswahili) and European languages (French, Flemish, Swedish, Gaelic, and English) that were present in the nineteenth century in the vast territory of the Congo Free State is yet to be studied. As early as 1908, when the territory came under Belgian rule, the obligation to teach French language and culture replaced (over time) instruction in African languages at missionary schools. These early textbooks written in vernacular idioms have been long neglected and should be collected and studied, but also questioned with regard to their purpose. Yet, alongside the monolingualism imposed by the colonial school, vernacular practices that had nothing to do with books continued to exist. In this respect, Bogumil Jewsiewicki, an anthropologist who has spent many years in the DRC since the 1970s, proposes the concept of "post-scriptural orality." He argues that the Congo's modern urban society has never questioned the prevalence of oral vernacular communication and of multilingualism vis-à-vis the authoritarianism of the bureaucratic hegemony of the written word:

Since colonization, there have always been ... hegemonic languages: French for writing, and a written, and therefore "modern," vernacular language for oral communication [Lingala above all, Kikongo and Kiswahili]. None of them, not even the tshiluba - the most localized in its precolonial area - is a language of rural society transplanted to the city. All were "fabricated" in a tension between the "invention" of a model set in writing and indiscipline induced by creolization. Some, such as Kikongo, a lingua franca, have been marked in their name: "ki-Eta" (ki-State: state language). All of them were adapted to the colonial society of which they had to organize the communication, respecting the hierarchical order when they were taught and standardized with the help of grammars,

9 For more on the issue of diminishing the Eurocentric perspective in African Historiography see, for example, Conrad and Randeria.

10 I use quotation marks because many anthropological studies have shown how inappropriate it is to link a national belonging to linguistic-cultural realities that are found, for example, in the border area around the Virunga volcano, in the so-called Great Lakes region. In this regard, see the recent study by Gillian Mathys, Barriers to Understanding: Questioning Territories and Identities in the Pre-colonial Lake Kivu Region, paper given on ${ }_{17}$ Nov. 2020 at the Académie Royale des Sciences d' Outre Mer, Brussels. 
manuals, missionary magazines. They were "disguised" (domesticated) when practiced by the colonized. ${ }^{11}$

"Vers une impossible" 102

Jewsiewicki illustrates this situation with an anecdote: when he freshly arrived in Mbandaka (the capital of Équateur Province) in 1968, he became interested in the Lomongo language and was politely referred to the "'most expert speaker' of this language, the Flemish Father Gustave Hulstaert" (103).

In the colonial era, representations of the individual's capacity for multilingual expression are to be found mainly in urban forms like visual media and music, the post-scriptural artistic tools by which the representation of the self is "as intense as elsewhere but [...] simply not taking place where most university professors would like to find them" (Jewsiewicki "Residing in Kinshasa" 105). ${ }^{12}$ Let's start with the visual. The advantage of the composite nature of the image is that

the "dit" - orality - uses neologisms, and words from other languages. The visual combines, and often opposes, the image and the writing. The heterogeneity of the representation is highlighted. In painting, in texts and in songs, by the juxtapositions of words, colors, and sounds, each element preserves its identity. The whole thing is more like a kaleidoscope than a still image. The representation of beings and things is generalized; contours are sketched in because the purpose of the image is not to teach. All know the history that is part of the common heritage. The point is rather to initiate the exchange of memories and experiences. The challenge is to make them contemporary in order to give them meaning, and, as such, to guide action in the "here and now." 13

"Vers une impossible" $105^{-6}$

11 "Depuis la colonisation, il y a toujours eu, dans le champ de la modernité, des langues hégémoniques: le français pour l'écrit et une langue véhiculaire écrite, et donc 'moderne', pour la communication orale. Aucune d' entre elles, pas même le ciluba - la plus localisée dans son aire précoloniale - n' est une langue de société rurale transplantée en ville. Toutes ont été 'fabriquées' dans une tension entre l' 'invention' d'un modèle fixé par écrit et l'indiscipline induite par la créolisation. Certaines, comme le kikongo, langue véhiculaire, en ont été marquées jusque dans leur nom 'kileta' (ki-l'État: langue de l'État). Toutes ont été adaptées à la société coloniale citadine dont elles avaient à organiser la communication, en respectant l' ordre hiérarchique lorsqu' elles étaient enseignées et standardisées à l' aide de grammaires, manuels, revues missionnaires, tout en le 'travestissant' (domestiquant) lorsqu' elles étaient pratiquées par les colonisés entre eux." My translation.

12 This is also Alena Rettova's (2015) argument about where to find African philosophy.

13 'Le 'dit' a recours aux néologismes, aux mots issus d' autres langues. Le visuel combine, 
As far as music is concerned, in an essay significantly titled "Inviting Marianne to Dance," Míde Ní Shuílleabhaín illustrates the case of the so-called Rumba Lingala. This music is based on a pidgin-born language initially spoken between the end of the nineteenth and the beginning of the twentieth centuries, mainly in the military urban environment. Due to its ease of morphosyntax, Lingala is widely used today, particularly in Kinshasa and throughout the northwestern part of the DRC, in the Republic of the Congo, and also in other parts of the continent, such as Kenya. Lingala is sociologically characterized by encounters, trade, and mobility. Its hybridity easily translates the multicultural and multilingual amalgam of the music that is imposing itself not only in the Congo but also across sub-Saharan Africa. Once again, as in the case of "sape,"14 "the insertion of French phrases into Lingala lyrics often represented a (re)appropriation of the colonial language and, as a result, a subversion of the colonial relationship" (Ní Shuílleabhaín 114). If this strategy of asserting Congolese agency through the appropriation of the colonial language is unexceptional in a colonial context, the contemporary use of Lingala in European hip-hop, Afrobeats, Afro-trap urban styles imagery is less evident, especially when there is no direct relationship with the African country, or its "metropole," Belgium. In this respect, Ní Shuílleabhaín reminds us that Maître Gims and other members of the French rap group Sexion d'Assaut recount a "story of a second-generation immigration experience in France through references to the African heritage of many of the groups' members" (116). Some words of the song "Sapé comme jamais" ("Fly as Ever") are in Lingala (Maître Gims), and it was ranked number one on the streaming charts in France in October 2015, above Adele's international hit "Hello." More recently, the Kinshasa-born

et souvent oppose, l'image et l'écrit. L'hétérogénéité de la représentation est mise en évidence. Finalement, dans la peinture, dans les textes et dans les chansons, on signifie par des juxtapositions de mots, de couleurs et de sons, chaque élément conservant son identité. Le tout a plutôt la forme d'un kaléidoscope que celle d'une image fixe. La représentation des êtres et des choses est sommaire, les contours sont esquissés parce que le but de l'image n' est pas d' enseigner. Tous connaissent en effet l' histoire qui fait partie du patrimoine commun. Il s' agit plutôt d'initier l'échange des mémoires et des expériences. L'enjeu est donc de les rendre contemporaines afin de leur donner un sens, et à ce titre, de guider l'action dans l' 'ici et maintenant." My translation.

14 The "sape," from which the verb saper refers to "Société des Ambienceurs et des Personnes Elégantes." It refers to a movement especially widespread between the capitals of the two Congos (Brazzaville and Kinshasa), initially born as a counterculture to compete with the dandyism of the "Bароро," the French colonial workers who came to these countries in the 1920s. The "sapeurs" transform and reuse their expensive abandoned clothes, and this has become a way of life, and a symbol of "cultural heritage" since the 199os. See Ch. Didier Gondola. 
artist Fally Ipupa is trying to spread a new musical style called tokooos, the word being "a derivative from the Lingala word kitoko, meaning 'something good' or a 'good vibe." ("Tokooos") The album Tokooos II (released in 2020), and particularly the song "Juste une fois" ("Just Once"), has reached a very high position on the iTunes sales charts in France, Belgium, and many other French-speaking African countries. Its music video begins with a reading in Lingala in which the French language is interspersed (See Ipupa).

The observation of these examples of linguistic pluralism in painting and music lead us to reflect on the necessity of resuming (reprendre) the thread of a narrative that for too long has insisted on monolingualism as the inescapable outcome of colonization first, and then of decolonization "on tutelage." At the same time, a necessary recast invites us to not automatically associate the use of African languages with a more authentic and therefore free possibility of expression. To illustrate this claim, I will now bring up a third example, this time taken from the literary field. To belie the simple equation between colonialist principles and the hegemonic language (in this case, French), the Congolese artist Sammy Baloji's exhibition "A Blueprint for Toads and Snakes" $(2018)^{15}$ takes as its point of departure the Kiswahili play Chura na Nyoka (The Toad and the Snake), commissioned by the Belgian colonial regime and written in 1957 by Congolese and Katanga-born (the mining region of DRC) Joseph Kiwele (1912-1961). Chura na Nyoka tells the story of a toad and a snake who are unable to maintain a friendship due to their inherent biological differences. Sammy Baloji links its metaphorical message of racial segregation to the blueprint of urban planning in the "native city" of the provincial capital Lubumbashi. As the exhibit's curator, Vincent van Velsen, states, Chura na Nyoka is

15 The work of artist Sammy Baloji "deals with the cultural, social, architectural and industrial heritage of his home country, the Democratic Republic of the Congo (DRC). With a background in photography, Baloji has developed a research-based practice in which archival material and cultural artefacts inform his work. By way of his art, he explores the histories, present-day realities and contradictions inherent to the formation of Congo in general, and its south-eastern province Katanga in particular: the resource-rich region which contains staggering amounts of mineral deposits. In this research he traces how (often colonial) powers created an infrastructure for the expropriation of raw materials, which led to a social classification that is often still visible today. The mines determine the entire economic and social life, leaving a huge void after their departure or relocation. The only thing that remains alongside old hierarchical structures is irreversible damage to nature and the environment, unemployment and a lacking economic infrastructure" (Velsen). 
an indicative part of a more elaborate Belgian endeavor to gain and maintain power through a divide and conquer politics, in which education collided with the imposition of lifestyle through "civilizing" policies and urban planning. Within this colonial politics, theatrical plays were performed by children: what is learned in the cradle is carried to the tomb. $[\ldots]$ The message that could be derived from both Chura na Nyoka and the urban planning of Lubumbashi's indigenous quarter Kamalondo, which implied several ideas of ethnic segregation by building a so-called cordon sanitaire - a neutral buffer zone, inscribed in the landscape, in order to effectively separate the European and Congolese population, was "a social engineering of society via the built of environment and cultural imposition" that explicitly suggested that "toads" and "snakes" do not belong together, while birds of a feather flock together.

Velsen 10

The use of local languages is thus not necessarily a guarantee of a lack of subordination, or of insidious power.

Conversely, we can find in recent years some récits de vie, or life stories, written in French that share the oral ambition to activate memories in order to reprendre (resume, recast) the thin red line of an interrupted but now common history. The family saga written in French by Clémentine Faïk-Nzuji, Tu le leur diras. Le récit véridique d'une famille congolaise plongée au coeur de l'histoire de son pays (You'll Tell Them: The True Story of a Congolese Family Plunged into the Heart of the History of their Country) or, more recently, her childhood memories in Si le Congo m'était conté (If I Was Told about the Congo) recast tranches de vie, or slices of life, of men and women who "through the vagaries of life" became "discrete witnesses or actors of decisive changes in their society," from the Belgian colonization of the Congo to the present day (Faïk-Nzuji 2005, back cover). In 2020, U.S.-based author Pius Ngandu Nkashama published his autobiographical testimony devoted to a member of his family: Mon Grand Père et la Conquête de la paix (My Grandfather and the Conquest of Peace). ${ }^{16}$ The choral and sometimes collaborative dimension (especially, but not exclusively, for women) prevails in this kind of expressiveness in which the question of lineage and filiation is paramount and where we can read the intertextual presence of Tshiluba epistemology and traditions in words, proverbs, genres, and tales. All these multilingual forms of expression (performed or literary) testify

16 Pius Ngandu Nkashama was a pioneer in the literary diffusion of the Tshiluba language, thanks to the publication of several works, among which we must mention the last one, Mwana wa Mulongeshi wanyi (2013). 
to the interconnection between oral sources, performative devices, and written cultures. They could be considered strategies of resistance or the result of intercultural coexistence brought about by the use and reuse of different languages and tools (post-scriptural/visual/musical/scriptural throughout "oraliture"17).

Other examples of non-metropolitan European languages demonstrate that diasporic, multilingual literature is not only postcolonial (i.e., aimed at writing against Western hegemony in the era of Independence) but colonial too. I refer first to a text published in Spanish, in Madrid, in 1949 - that is, at the very beginning of Congolese literature in French - by Francisco-Jose Mopila, Memorias de un Congolés. Ensayo de auto-biografia (Memories of a Congolese: An Autobiographical Essay). This autobiography shows the full potential of a Congolese liberated from the colony. Born in 1915 to Azande parents, Mopila became the assistant of a Spanish doctor, Rodrigues Terrazas. When, in 1936, the doctor finished his contract in the Congo, he invited his young protégé to Spain. In 1939, at the end of the Spanish Civil War, Mopila moved to Madrid, where he enrolled at the Academy of Fine Arts and became a sculptor. Mopila's autobiographical novel (translated into French in 1972 by Mont Noir, a publishing house founded by V.Y. Mudimbe in Kinshasa) is a realistic chronicle of the Belgian Congo of the 1920s and 1930s, rich in geographical, historical, and anthropological details. But unlike other novels circulating at the same time by authors living in the Congo, Memorias de un Congolés openly criticizes colonial abuses and cruelty.

The second example concerns the English language: I became aware of the existence of a manuscript of about thirty pages written in English by a Congolese who visited the United States in the 1940s. ${ }^{18}$ Unfortunately, this essay is still unpublished, like probably many others sleeping in drawers around the world. There is a lack of awareness of the cultural importance of these documents, and also of infrastructures that could make texts like this available to the larger public. It could show that, for example, in the U.S., of the colonial Belgian Congo culture remains more than the sad memory of Ota Benga (18831916), born into the Mbuti Pygmy colony of the Congo Free State and exhibited in the Bronx's New York Zoological Gardens in a monkey house, or the designation of New Orleans' Congo Square as an urban setting for early Afro-American

17 A neologism introduced by the Martinican writer Patrick Chamoiseau in the novel L'Esclave Vieil homme et le molosse (1997; trans. Slave Old Man, 2018) to indicate everything that, in written form, translates the spoken word ("la parole").

18 I thank London-based journalist and writer Norbert Mbu-Mputu for this news. 
music. ${ }^{19}$ These examples suggest that multilingualism can reopen the colonial narrative of imitation and assimilation to the consideration of their function within the metropolitan linguistic and literary fields.

Last, we also need to reevaluate the predominance of oral communication in linguistic pluralism confronted with the authoritarianism of a bureaucratic hegemony of writing. Let's take the crucial historical moment of the end of the Cold War in Africa. As Jewsiewicki shows,

[i]n 1990 in Congo, the sudden end of the state monopoly on the press and radio triggered the creation of some one hundred newspapers, most of which quickly shut down. Despite the existence of a few radio stations, one needed batteries (which are expensive), since many neighborhoods had no electricity; newspapers were unaffordable, and only available in the center of town. Sidewalk radio (radio trottoir), urban rumors (see Nlandu-Tsasa, 1997), are responsible for disseminating information in a manner that is available to all. At the hubs of all the large transportation networks, or close to the gas stations, vendors come together to spread out their wares, including one copy of each newspaper. Every day, someone took responsibility for listening to and noting the day's news. The listener in turn communicated the news and a discussion followed. Information [was] thus garnered from a mixture of local and international mass media, the local press (itself often listening to ambient rumours), and real rumours, which are then put into oral circulation from ear to ear.

"Residing in Kinshasa" 110

These practices coincided with the end of the Mobutu dictatorship in 1997. If, in 1998, 6o percent of the residents of one neighborhood in Kinshasa (Ngaba) "still claimed never to have used a telephone in their lives" (Saint-Moulin 439), nowadays, mobile phones make possible the need of many Kinshasa artists and writers to encounter the world. From this point of view, it is interesting that almost every day, from his Facebook account, the young literary talent Sinzo Aanza (born in Goma, 199o) writes stories about Kinshasa to a fictitious "Papa Robert" who elected him "Poet of the city."20 The writers' use of cell phones is

19 See Johnson.

20 Sinzo Aanza is not only a poet but also a visual artist and a playwright (Que ta volonté soit Kin, 2018 et Plaidoirie pour vendre le Congo, 2020; translated in English in 2021 as A Plea to Sell the Congo by Madhuri Mukherjee, Rutgers School of Arts and Science, Department of French). He is the author of short stories, plays and essays, and a significant first novel Généalogie d'une banalité (2015; also translated into German). His writings and plays ques- 
also a way to cope with the very difficult conditions of the country's electricity network: the continuous power cuts do not allow the safe use of fixed computer stations. We have thus gone from rumors to noise - that is to say, to a loud and affirmative expression of the self. ${ }^{21}$

In this first part, I have shown that the consideration of a multilingual landscape and of the complexity of language uses in written texts dismantles some stereotypes of the traditional history of colonialism (for instance, the idea of an interruption of precolonial languages and forms). Needed updates (and recasts) thus include the following:

- Vernacular languages coexisted with French in popular painting and music from the very beginning of colonization, and they are enjoying new successes in today's artistic spheres.

- Colonial propaganda used vernacular languages (e.g., Kiswahili in Lubumbashi) more often than expected to consolidate its rule.

- Some precolonial oral forms (such as the kasala in Tshiluba tradition) are being reactivated today in life stories in French and, more recently, in performative forms of "oraliture."

- Nowadays, some European rappers or slam poets who have no relation to the former colony use Congolese languages - particularly Lingala - to celebrate the hybrid condition of migration, as if Lingala had become a cosmopolitan language.

- Diasporic literature in languages other than the metropolitan ones do not coincide with the end of colonization, but coexist, albeit in a minority way, with colonization itself.

- The predominance of oral communication in linguistic pluralism when confronted with the authoritarianism of a bureaucratic hegemony of writing has yet to be studied.

\section{$3 \quad$ Restitution in Literature}

I now move on to the idea of reading together. Together with what, and with whom? The theory of "significant geographies," introduced by the ERC project "Multilingual Locals and Significant Geographies" and based on studies by the geographer Doreen Massey, teaches us that "any 'simultaneity' of stories-sofar will be a distinct simultaneity from a particular vantage point" (Laachir,

tion justice and the political situation of the DRC, as well as the image of this country that has always been in the hands of foreign investors.

21 See Ndaliko. 
Marzagora, and Orsini 293). This involves reading together local, national, and transnational languages and texts, with the subsequent semiotic translation of the various concepts that each of these languages and imaginaries convey. Mudimbe's "Explorations on Intellectual Ethnicity, Philosophy and Ethnological Reason, in Conversation with Sam Okoth Opondo" can help us to interpret this statement. Mudimbe refers to Tour du monde des concepts (Going around the World of Concepts), a book edited by Pierre Legendre in 2014. Mudimbe and Opondo define this book as

an intercultural manifesto in its own right. It brings together a number of languages (Arabic and Persian, Chinese, Hindi, Japanese, Russian, Turkish and African languages ${ }^{22}$ ) and dwells on the circulation of concepts dealing with the truth, the law, the contract, as well as everyday life in relation to nature and our present-day social institutions, such as the State and society. Suresh Sharma notes in his postface, and very correctly, that "the philosophical and linguistic exercise that Pierre Legendre initiated is an invitation that interrogates the nature and implications of relationships between language and thought in modern contexts."

MUDIMBE and OPONDO 7

This questioning of the nature and implications of the relationship between languages and thought, but also between disciplines and devices in the contemporary world, must start from rethinking and questioning established divisions (e.g., French = worldly; Lingala = local; literature = printed books; consecration $=$ literary award).

I'll start with a literary case. In 2016, Richard Ali A Mutu's Embaba Kinshasa Makambo (lisolo) was the first novel to be translated from Lingala into a European language, and was released in English in the United States under the title Mr. Fix-It, without going through the usual French-speaking network. The book's English translation could be explained in postcolonial and transnational ${ }^{23}$ terms as an example of the dynamics of circulation and legitimacy between center and periphery, Paris being simply replaced with New York. One could also add that the book has enjoyed significant international success in an "autonomous international literary field" (Sapiro and Ungureanu 161): Richard

22 The languages of Burkina Faso and Gabon.

23 I am referring to Pascale Casanova's works as a "transnational" approach because she "describes the emergence and development of an autonomous international literary field in opposition to the instrumentalization of literature for the construction of national identities" (Sapiro and Ungureanu 161). 
Ali A Mutu was the only Congolese featured in the anthology Africa3g: New Writing from Africa South of the Sahara, published by Bloomsbury in October 2014 with a preface by Nobel Laureate Wole Soyinka. It would be interesting to understand not only how but also why this happened; the fact is that significant geographies do not necessarily correspond to determinism and expectations, and it is important to stress that recently literary production in Lingala has seen a boom in the Congo. ${ }^{24}$

Of course, we must keep in mind that we read literary "facts" retroactively. As Mudimbe and Opondo would say, we all depend on a cultural context - that is, our own:

The place of enunciation is important. This could determine the ways in which we look at intellectual problems and how we treat them. But, on the other hand, these qualifications do not necessarily determine our thinking, they are circumstantial and we must avoid them inflecting our analysis.

MUDIMBE and OPONDO 4

This is the reason why plurality and teamwork are necessary. Such has been the basis of the literary facet of the project "Mobility-Stabilization. Congolese Representations and Social Dynamics, in Congo and in the Global Space," ${ }^{25}$ which resulted, among others, in the publication of the issue "Global Congo: Politics, Aesthetics of a World Literature" in the French journal Continents Manuscrits, dedicated to the words of Congolese writers and cultural actors (including publishers, translators, and intellectuals) ${ }^{26}$ The "Mobility-Stabilization" project aimed at making intercultural history from below, and at opening up to Citizen Science, thus improving cross-agency collaboration. The purpose is not necessarily only linguistic or intercultural - in other words, it is not a "tour of the Congo" from the vantage point of its multilingual literatures, but an invitation to see and explore, through data, unexpected routes, contingencies, and contiguities, as well as neglected links within "systemic"27 literary history. So far, this project has encountered obstacles linked to the particular dynamics prevailing in the planetary sharing of resources - in this case, of data (not just

\footnotetext{
24 See Gombo.

25 This article is an output of the "Mobility-Stabilization" project, which has received funding from the Italian Ministry of University and Research (MIUR) under the PRIN Research and Innovation Programme under grant agreement No. 2015 JSsXC4.

26 See Gombo.

27 I refer here to the architectonic of systemic knowledge evoked by Mignolo 2011.
} 
bibliographic) and primary resources (such as full texts that could make use, for instance, of the Creative Commons license).

This perspective distances itself from Pierre Bourdieu's notion of "literary fields," (3-46) which has been studied in a remarkably accurate way by Pascale Casanova, who, however, finds it hard to imagine (and therefore show) any forms of logic that are different from those that are systemic (or transnationally polysystemic) and polarized. The "Mobility-Stabilization" project is equally aimed at seeing and exploring the historical and contemporary reasons for the lack of reciprocal relations between certain literary phenomena. I will return to this lack in the latter part of this essay, when I consider the literary field in tropological terms.

The first meaning of restitution is thus the reorganization of knowledge and discourse around the (Congolese) literary matter through collaborative reading or, better, reading through each other. Plural teamwork is also necessary because the panoply of languages in which Congolese creativity is expressed is so great that no single individual can grasp them all: Lingala, Tshiluba, Kiswahili, Kikongo, Elonga, French (in its different variants - for instance, the novels of the Quebec-based Blaise Ndala ${ }^{28}$ ), English, Spanish, German, Italian, and Flemish. Chinese could be added to this list, since it is already used by In Koli Jean Bofane's chapter titles in Congo Inc. ${ }^{29}$ The corpus is huge. It is even larger if one includes archives and unpublished materials, which exist but lie forgotten in the stores of publishing houses (among others, I think of Présence Africaine in Paris), or hidden in the trunks of the authors' families, or in religious convents.

For this reason, it is necessary to ensure the acknowledgment, and hopefully the participation, of publishers and critics. Glopro, a publishing house active until 2010 in Sudbury, Canada, has ensured the printing of numerous texts (such as essays, poems, novels, and short stories) in Tshiluba, a language from the Kasai area ${ }^{30}$ that has an important literary status. To give one example, Pius Ngandu Nkashama has taken up the Luba traditional literary genre of the kasala as a matrix for one of his texts written in French and published in France

28 See the Works Cited.

29 See Duncan M. Yoon's article in this same issue.

30 The Kasai province, in the southcentral part of the DRC, is one of the twenty-one new provinces created in the 2015 repartition of the nation. After their independence from Belgium in 196o, Kasai has had a secessionist phase, which came to an end with the assassination of Patrice Lumumba. The region, divided into western and an eastern parts until 2015 , saw the outbreak of a violent rebellion in 2017 , which resulted in the displacement of about 1.5 million people, mostly children. 
in the 1980s, then translated into English in 2019 under the title Blood Pact. Other symbolic and ritual objects taken from the Luba culture can revitalize not only Congolese writers: Consider the lukasa, a memory board or mnemonic device traditionally used by experts to read Luba history by touching pearls and embedded signs on a piece of wood. It has been used as a chronotope around which some authors have constructed an imaginaire - in particular, in Lagoon, lagunes, written by Sylvie Kandé, a French-Senegalese poet living in New York, and published by Gallimard. The publishing house Mabiki, based in Belgium and the DRC, is also significant - led by Bienvenu Sene Mongaba (cotranslator, along with Sara Sene, of Mr. Fix-It), Mabiki publishes literary and scientific works mainly in Lingala, but also in Kiswahili.

As far as literary criticism is concerned, Haiti seems to be the place where the nodes of the Global South meet. ${ }^{31}$ Interviewed by Jean Jonassaint in the issue of Continents Manuscrits dedicated to the "Global Congo," Elisabeth MudimbeBoyi shows that the first independent Black state of the modern world, Haiti, and the Congo were engaged in intense cultural exchanges during the $196 \mathrm{os}^{32}$

Reading together also means recognizing the "multilingualism of the Other" - to take up and expand Derrida's famous phrase (1997) - in order to get away from the determinism of recognition dynamics that feeds the void where African literatures have been often confined for lack of critical commitment and fieldwork-research efforts. This also means challenging established hierarchies and general disengagement. It is clear that, in this sense, informal, fragile local networks spanning remote places are as important as symbolic capitals. Pheng Cheah understands world literature as "both a site of processes of worlding and an agent that participates and intervenes in these processes" (2). More and more African writers live between continents and languages while being rooted in their own imaginary, and they write literature without borders - literature that is neither singularly linguistic, disciplinary, or territorial. I will include an example from the intersection of different disciplines and horizons. But I would first like to note that if these writers sometimes do not escape the process of worlding from the point of view of politically "liberal" dynamics, and if they nevertheless seek consecration from recognized circuits, they increasingly realize that there is also a planetary agency that goes far beyond our human worldly contingency that literature and art are perhaps able to enhance.

31 For this concept, see West-Pavlov.

32 See Gombo. 
Let's thus take a performative example related to the cross between written literature and the performing arts. In 1979, a few years after the "Suns of Independence"33 showed their sad shine, the Ivorian writer Bernard Dadié composed Mhoi Ceul, a play in five acts. The French pronunciation corresponding to moi seul ("only me") translates the model of selfishness of an opportunistic, corrupt, and arrogant young executive who considers himself above everything and everyone - especially his subordinates, including the elderly Kabako who, at the end of the play, will triumph. Many years later, in the early 2ooos, Kabako, the character who is the exact opposite of a selfish bien nommé ("elite"), was chosen by the choreographer and storyteller Faustin Linyekula to baptize his contemporary dance company and arts workshop Studios Kabako in Kisangani (the town in which V.S. Naipaul's $A$ Bend in the River is set). ${ }^{34}$ In his numerous works that have traveled around the world, Linyekula has never stopped reflecting on the future of Congo, starting from the places where the ordinary, overlooked Kabako humans live. These places are informal and fragile. They include the haunting forests of Hevea, from which "red rubber" was extracted, and which Linyekula used to stage his 2019 performance piece Congo, from the eponymous book by Éric Vuillard; ${ }^{35}$ and the suburbs of peripheral cities such

33 I am referring to the masterpiece of the African modern novel: Les Soleils des Indépendances (1981), by the Ivorian novelist Ahmadou Kourouma.

34 "His career as a choreographer has taken [Linyekula] to the Comédie Française (with Bérénice in 2009) and the Ballet de Lorraine (La Création du monde in 2012), and he has performed at venues that include the MoMA in New York (2012), the MUCEM in Marseille (2016) and the Royal Museum for Central Africa in Tervuren (2018). [He] is the associate artist at the Manège-Scène nationale de Reims in France and at the Holland Festival in Amsterdam, as well as teaching at Parts (Anne Teresa de Keersmaeker's school), the CNDC Angers and the Impulstanz festival in Austria. [...] In 2001, he founded Studios Kabako in [Kisangani], an organisation dedicated to dance, theatre and video arts. [...] Studios Kabako $[\ldots]$ are committed to developing the young generation of African artists and giving them the tools to create." ("Lettres du continent") There is also a biographical reason for the choice of this name for the company: Richard Kabako was Linyekula's childhood friend who died of bubonic plague near the border with Uganda. His story is allegorical: "It tells a familiar tale of dissolution and flight, of hope met by oblivion and an unmarked grave. It is a story that exceeds Congo, a story that is replayed almost daily in failed passages across the Mediterranean. But, in Congo, Kabako's unceremonious burial invokes the memory of Patrice Lumumba, the country's short-lived, first democratically elected president whose assassination in 1961 was followed by burials, exhumations and the eventual disappearance of his body" (O'Toole).

35 The choreographer of Congo explains that it is a dance composition, an actor's piece by Daddy Kamono Moanda and by Pasco Losanganya, also an actress, but who, in this piece, sings. She is inspired by the songs of the Mongo people, living in the northwest of the country. It is in this area where she was born that the atrocities of the "cut-off hands" described by Éric Vuillard took place. 
as Lubunga, on the south bank of the Congo River, where Linyekula built a pilot water treatment facility that reconciles culture and sustainability. ${ }^{36}$

Some of the events of today's changing climate (extreme flooding, lack of water, tornados), pandemics, or volcanic activity (like the earthquake in Goma, eastern DRC, when Mount Nyiragongo exploded in 2002 and 2021) suggest that the end of human history is possible, and this potential end is the reason why the current issues of identity are often reconsidered in the name of community. The agency of nature is challenging the power of culture: in this situation, collectivism could rehabilitate a broken community, and writers (more and more without borders) could take on the role of pointing out emergencies and could, in some cases, try to heal them. I will now move on to the fourth and final part of this essay, which will introduce a new metaphor, taken from the field of botany by French gardener and philosopher Gilles Clément, to describe a possible new way of recasting, reading, and applying the category of restitution to global or rather planetary - Congolese literature.

\section{From Global to Planetary: The "Third Landscape" Metaphor Applied to (Congolese) Literature}

In a recent essay (Riva 2017), I tried to demonstrate that the metaphor of "Third Landscape" introduced by Gilles Clément in 2003 in his Manifeste du Tiers Paysage (The Third Landscape Manifesto $)^{37}$ could be used to explore any literature belonging to the world as a means to escape the approach of polarized logics resulting from dualistic thinking (We/Others). Today, we can no longer critically envisage the multiplicity of cultural expressions by anchoring an author or an artist (from any place) to his/her own country of origin, or through the condition of expatriate or ex-colonized person. That being said, it is necessary to consider the situation of enunciation of those who express themselves through any sort of mobility (material or immaterial). "Border thinking,"38 as an alternative way to grasp literary phenomena, allows us to speak about "metonymic" societies - that is, societies informed (but not contained) by globalization, and ones that are forced into contingency (compared to the mainstream) that is sometimes desired but sometimes imposed by circumstances. In other words,

\footnotetext{
$3^{6} \quad$ See Lyniekula.

37 For a partial translation into English, see Clément 20o3b. All the quotes are taken from the French online edition (Clément 2003a) and translations are mine.

38 Walter D. Mignolo and Madina Tlostanova describe border thinking as "the epistemology of the exteriority; that is, of the outside created from the inside" (206).
} 
it is possible to adopt an epistemological perspective that considers the existence of situated knowledge capable of combining the local and the globe. ${ }^{39}$

However, as previously mentioned, it is becoming increasingly clear that we must also consider the world in its physical agency. Thinkers such as Dipesh Chakrabarty, among others, are helping us to highlight this point. In a January 2020 conference that took place in Lisbon for the tenth anniversary of the release of his important paper "The Climate of History: Four Theses," Chakrabarty invited his audience to consider the difference between time on the global scale - that is to say, the time in which we, humans, move sand to build infrastructures, dig mines to extract raw materials, or consider the idea of sustainable economy - and time on the planetary scale, which is not measured by the clock or by human needs. The latter is geological time, in which sand moves us, everything around us, and everything that will be left after the eventual disappearance of humans. From this large-scale point of view, economy is, in some ways, always sustained.

Now, the only way to imagine a time without humanity or with another kind of humanity - extremely remote or extremely future - is through art and literature. We can list plenty of post-apocalyptic or novels or films on the subject. Recall, among the usual dystopian fare, the Marvel Studios film Black Panther (2018), which proposes, in connection with Afrofuturism, a futuristic utopia for Africa. ${ }^{40}$

39 In "From Cosmopolitanism to Planetary Metonymy and Back," I tried to show that the issue of cosmopolitanism has always been connected to a universal project, most of the time conveyed in a metaphorical way. What we are facing in our globalized world is a state of contiguity in a certain space, where the contingency is increasingly perceived. Tropologically speaking, we live now in a S/state that is partially metonymic (contingent) and partially metaphorical (that is to say, founded on the myth of a common history). My proposal to apply the ecological concept of "Third Landscape" taken by Gilles Clément in this model has the merit of considering the community in metonymical terms (contiguity and contingency) without forgetting the planetary utopian dimension (metaphorical myth of world as unity) inherent, after all, to any cosmopolitanism and to literature. This new perspective of mine has nothing to do with the concept of hybridity introduced by, among others, Homi Bhabha, since the Third Landscape applied to literary phenomena does not at all imply identity issues.

40 First used by Mark Dery (1994), this concept presents new alternative memories and new imaginaries of the future. According to Dery, it is a "speculative fiction that treats African-American themes and addresses African-American concerns in the context of twentieth-century technoculture - and, more generally, African-American signification that appropriates images of technology and a prosthetically enhanced future" (180). Afrofuturism has been experiencing renewed interest for a few years now, in order to "to tell and build, in new ways, the world we (used to/want to) live in: inclusive, sustainable and unabashed" ("Blacks to the future"). 
An example of what could really happen when humans withdraw from the streets was concretely experienced in some countries during the first coviD-19 lockdown in early 2020 . The skies cleared, vegetation writhed up through the asphalt, and wild animals came to the city centers - this is where the concept of the Third Landscape comes into play. According to Gilles Clément's Manifesto, the Third Landscape consists precisely in the unexpected overtaking of nature in areas abandoned by humans (cities, in particular): it thus reveals the artificial dimension of what appears to be "naturally" present (for instance, fast-growing managed pine forests or pasture lands). The Third Space areas are fragments of the landscape that are very dissimilar but have one thing in common: they constitute a territory of refuge for diversity, such as flowers, insects, and vegetation. They are mobile and dynamic, both through the interplay of internal exchanges and through interaction with the surrounding environment; their fate is undecided, and their evolution erratic. Finally, they eschew the idea of heritage, which would condemn the Third Landscape to its own disappearance - and yet, they change form through the play of the market and politics. The Third Landscape is opposed to the idea of a nature preserve, those unexploited areas which, for several reasons (difficulty or cost of access, or those that are off-limits due to religious prohibitions), are kept outside the anthropized environment. The Third Landscape is also opposed to primary ecosystems or spaces (oceans, forests, swamps, mountain peacks) that have never been subject to exploitation and are increasingly limited. The last paragraphs of the statute of the Manifesto state that "the Third Landscape acquires a political dimension by its content, by the stakes involved in diversity, by the need to preserve it - or to maintain its dynamics"; it "coincides with administrative delimitations on a temporary basis"; and moreover, "the maintenance of its existence does not depend on wise men, but on a collective conscience." Finally, as Clément poetically states, "the boundaries of the Third Landscape are the boundaries of the Planetary Garden, the limits of the biosphere."41 In an interview, Clément reprises the meaning of this concept:

Basically, every action taken by humans on earth results in some kind of leftover - "délaissé" in French. There is always a part that is not addressed. Up to now, humans haven't demonstrated that they have the capacity to understand the planet comprehensively. Even with places that are well thought out and cared for, that very activity seems to generate areas at the periphery (and sometimes in the center) which are not considered 
at all. They once belonged to the same nature, but have been destroyed. Freeways, with their on- and off-ramps, for example, produce an enormous amount of leftover space. Just imagine this at the scale of the entire earth: a giant leftover dominated by human activity, with very few nature reserves. It is necessary in terms of ecological balance to set aside large portions of space as Third Landscape, abandoned or transitional spaces whose fate is un-decided. The Third Landscape is not a garden; it is the genetic reservoir of the planet.

BRATTON 83

Border thinking, antisystemic views, and the Third Landscape bear remarkable similarities that can help us think about contemporary world literature's metonymical (contingent, partial) and metaphorical (unitary, total) properties: a giant délaissé ("remainder") to read (together) in a new way. Let's now revisit Clément's suggestions and try to show how and why this truly contingent territory can be applied metaphorically to literature. An important clarification: the Third Landscape corresponds to all unexpected natural or cultural inventions before their patrimonialization (i.e., the various rituals by which cultural features - either material or immaterial - are turned into a people's heritage). First of all, the Third Landscape speaks about neglected/abandoned ground, and ground is precisely where literary landscape and the artistic inventions are located. In other words, there is always an anchoring between speech (or gesture, or visual imaginary) and the place from which these are settled, emitted, shot, or practiced. The landscape differs from the notion of the Bourdieuan "field": a field is defined by its delimitations, by its distinctive system, while the notion of landscape is open and inclusive. While a field can be seen in a systemic way, land itself is always only at a crossroads, if not at the edge of, or against several fields (systems). ${ }^{42}$ Land itself is dynamic.

42 To me, the notion of "Littérature-monde" presented in the famous Manifesto published in Le Monde (2007) and signed by a large number of French-speaking writers as well as a few French writers with the aim of freeing "Francophone" literature from its "pact with the nation" is still part of a systemic logic of inclusion (or fusion) and recognition. If the Manifesto speaks of the "Copernican revolution" of a French literature that now has its center everywhere ("révolution copernicienne. Copernicienne, parce qu' elle révèle [...] que $[\ldots]$ le centre, ce point depuis lequel était supposée rayonner une littérature francofrançaise, n' est plus le centre"), this same center is still defined in the Manifesto through the literary prizes that, traditionally in France, are awarded in autumn ("le centre, nous disent les prix d'automne, est désormais partout, aux quatre coins du monde", ("Pour une littérature-monde")). Emphasis mine. What has been called an overwhelming decentralization, in fact, remains a centralization of consecration (the great literary prize season in 
Just as in the Third Landscape, innovation in literature and in the arts (such as genre experimentation) takes place on the back of land that was once formerly exploited and is now abandoned, incurring the risk of momentary or definitive neglect and circumscription. In the same way, these innovations reveal the artificial character of what appears to be "naturally" present in literary studies: canons, the delimitations of literary or artistic genres (the problematic "magical realism" definition), the distinction between orality and writing, the partitioning between humanities and scientific knowledge, the assignment of a novel to one bookshelf rather than another, and the use-value of an object (for instance, a literary or cultural motif - for example, kasala or lukasa) or a technique, such as a figure of speech like hyperbole, used as the incipit of Bofane's novel Congo Inc., coincidentally entitled "Lands and Time":

\section{"Fuckin' caterpillars!"}

For more than an hour the exasperation the innocent little bugs had been causing Isookanga had stimulated his senses, enabling him to make his way more quickly through the forest, avoiding low branches, creating gaps in the foliage with the same determination as an icebreaker's bow at a time of global warming.

In these landscapes of contiguity and contingency, literature can enjoy mobility and dynamism, both through the interplay of internal exchanges (local) and through interaction with the surrounding environments (worldly). In the same way, its future is unpredictable and its evolution erratic. In relation to culture as a system, these literary spaces position themselves as refuge territories (passive) and as places for invention (active). Thus, in their initial practice, they escape the idea of patrimonialization, although in some cases, with or without the express consent of the author or artist, they may become "heritage." Literary space - as is the case for the Third Landscape - changes its forms through politics: choosing one idiom over another led the Kenyan writer Ngũgĩ wa Thiong'o to spend one year in prison in 1977, and yet choosing to write and to publish in Lingala, Tshiluba, or Kiswahili has a different ethical status nowadays. In contrast to the botanic Third Landscape, these lands of literary or artistic creation parasitize and sometimes try to insinuate themselves into the réserve ("pre-

France). The real Copernican revolution is the one that is beginning now to show, instead, the multiplication of centers of consecration, not necessarily but increasingly located in the writers' native countries. The multiplication of languages is also the origin and the consequence of this revolution. 
serve"), namely in places not exploited for multiple reasons. Here, it is sufficient to think of intertextual borrowing not as the traces of "postmodern" aesthetics, but as the capacity of an author to integrate and reinvent the vestiges of an earlier polyculture in her/his work. Finally, by their content, by the stakes involved in diversity, by the need to preserve them or to maintain dynamism, the undecided spaces of creation acquire a political dimension, and the maintenance of their existence does not depend solely on intellectual elites or on the cultural market (festivals, book fairs, publishers, curators, and writers' associations), but on a collective conscience. Because of this, they configure the future while reinventing it.

In the literary realm, Clément's ecological concept has the merit of considering community and nature in metonymical terms (contingency and contiguity, or the existence of literary expressions close to but not yet penetrated by majoritarian ones) without forgetting the metaphorical utopian planetary dimension (world as unity) inherent in any work of language or art. This concept's literary consequences avoid cultural essentialism. Including characteristics of many different geocultural units, the planetary model is, in fact, not monolithic; it is not located in a specific place. Geographically, symbolically, and ontologically, it can be made up of multiple worlds, or of parts of worlds stratified within each other, rather than organized according to vertical hierarchies. It is always dynamic and changing in the long run.

Precisely because of its historical internationalization, its multilingualism, and the creative freedom present within a geopolitical situation of extreme instability, Congolese literature is emerging as an exemplary laboratory of stratified global but not globalized worlds that show us the way to think on a collective and planetary scale, to think through each other, and to find common ground.

\section{Works Cited}

Aanza, Sinzo. Généalogie d'une banalité. La Roque d'Anthéron: Vents d' ailleurs, 2016. Aanza, Sinzo. Que ta volonté soit Kin. Kinshasa: Nzoi, 2018.

Ali A Mutu, Richard. Ebamba. Kinshasa Makambo (lisolo). Kinshasa: Editions Mabiki, 2014.

Ali A Mutu, Richard. Mr Fix-It:Troublesome Kinshasa. Trans. Bienvenu Sene Mongaba and Sara Sene. Los Angeles: Phoneme Media, 2017.

Bofane, In Koli Jean. Congo Inc. Le testament de Bismarck. Arles: Actes Sud, 2014. Bofane, In Koli Jean. Congo Inc.: Bismarck's Testament. Trans. Marjolijn de Jager. Bloomington: Indiana UP, 2018. 
Bourdieu, Pierre. "Le champ littéraire." Actes de la recherche en sciences sociales, 89 (1991), 3-46.

Bratton, Denise. "An Interview with Gilles Clément." $\log 12$ (2008), 81-9o.

Casanova, Pascale. La République mondiale des lettres. Paris: Seuil, 1999.

Casanova, Pascale. The World Republic of Letters. Cambridge: Harvard University Press, 2004.

Chakrabarty, Dipesh. "The Climate of History: Four Theses." Critical Inquiry 35:2 (2009), 197-222.

Chamoiseau, Patrick. L'Esclave Vieil homme et le molosse. Paris: Gallimard, 1997.

Chamoiseau, Patrick. Slave Old Man. Trans. Linda Coverdale. New York: The New Press, 2018.

Cheah, Pheng. What Is a World? On Postcolonial Literature as World Literature. Duke UP, 2016.

Ciocca, Rosella, and Neelam Srivastava. Indian Literature and the World. London: Palgrave Macmillan, 2017.

Clément, Gilles. Manifeste du Tiers-Paysage. Montreuil: Editions Sujet/Objet, 20о3a. http://www.gillesclement.com/fichiers/_tierspaypublications_92045_manifeste_du _tiers_paysage.pdf. 15 Apr 2021

Clément, Gilles. The Third Landscape. 2003b. http://www.gillesclement.com/art-454-tit -The-Third-Landscape. 15 Apr. 2021.

Conrad, Sebastian, and Shalini Randeria. "Geteilte Geschichten - Europa in Einer Postkolonialen Welt." In Jenseits Des Eurozentrismus. Postkoloniale Perspektiven in Den Geschichts Und Kulturwissenschaften. Eds. Sebastian Conrad and Shalini Randeria. Frankfurt a.M.: Campus Verlag, 2002.

Dadié, Bernard Binlin. Mhoi Ceul. Paris: Présence Africaine, 1979.

Derrida, Jacques. Monolingualism of the Other; or, The Prosthesis of Origin. Trans. Patrick Mensah. Redwood City: Stanford UP, 1997.

Dery, Mark. "Black to the Future. Interviews with Samuel R. Delany, Greg Tate, and Tricia Rose." In Flame Wars. Durham: Duke up, 1994, 179-222.

Faïk-Nzuji, Clémentine. Si le Congo m'était conté. Waterloo: Jourdan Editions, 2020.

Faïk-Nzuji, Clémentine. Tu le leur diras. Le récit véridique d'une famille congolaise plongée au cour de l'histoire de son pays. Congo (1890-200o). Bruxelles: Alice Éditions, 2005 .

Fraiture, Pierre-Philippe. "An untimely concept: decolonization and the works of Mudimbe, Mbembe and Nganang." In Doing Conceptual History in Africa: Making Sense of History. Eds. Axel Fleisch and Rhiannon Stevens. New York: Berghahn Books, 2018, 213-36.

Ghosh, Amitav. The Great Derangment: Climate Change and the Unthinkable. Chicago: University of Chicago Press, 2016.

Glissant, Édouard. Introduction à un poétique du divers. Paris: Gallimard, 1996. 
Glissant, Édouard. Introduction to a Poetics of Diversity. Trans. Celia Britton. Liverpool, Liverpool UP, 2020.

Gombo, Christian. "Oui, le Congo est un centre littéraire." In “Global Congo." Ed. Silvia Riva. Continents Manuscrits 15 (2020). Web. 25 Apr. 2021.

Gondola, Ch. Didier. "Dream and Drama: The Search for Elegance among Congolese Youth." African Studies Review 42:1 (1999), 23-48.

Ipupa, Fally. "Juste une fois." Youtube, uploaded by Fally Ipupa, 19 Feb 2021, https://www .youtube.com/watch?v=856_pQr3x7Q. 25 Apr 2021.

Jewsiewicki, Bogumil. "Residing in Kinshasa: Between Colonial Modernization and Globalization." Research in African Literatures 39:4 (2008), 105-19.

Jewsiewicki, Bogumil. “Vers une impossible représentation de soi." Les Temps Modernes 620-621:4 (2002), 101-14.

Johnson, Jerah. "New Orleans's Congo Square: An Urban Setting for Early AfroAmerican Culture Formation." Louisiana History: The Journal of the Louisiana Historical Association 32:2 (1991), 117-57.

Kandé, Sylvie. Lagoon, lagunes. Tableau de mémoire. Paris: Gallimard, 2000.

Kourouma, Ahmadou. Les Soleils des Indépendances. Montréal: Presses de l' Université de Montréal, 1968.

Kourouma, Ahmadou. The Suns of Independence. Trans. Adrian Adams. Teaneck: Holmes \& Meier, 1981.

Laachir, Karima, Sara Marzagora, and Francesca Orsini. "Significant Geographies In lieu of World Literature." Journal of World Literature 3:3 (2018), 290-310.

Legendre, Pierre. Tour du monde des concepts. Paris: Fayard, 2014.

Les Ateliers de la pensée. Les Ateliers de la pensée de Dakar III. 2019. https://www .thuram.org/wp-content/uploads/2019/10/Ateliers-de-la-pens\%C3\%Age-2O19-pr\% $\mathrm{C}_{3} \%$ Agsentation.pdf. 11 Nov. $2 \mathrm{O} 2 \mathrm{O}$.

Le Lay, Maëline. "Joseph Kiwele in Élisabethville (1946-1961) and the Birth of an Urban Culture in the Colonial Era." In A Blueprint for Toads and Snakes: A Solo Exhibition by Sammy Baloji. Eds. Sammy Baloji and Vincent van Velsen. Amsterdam: Framer Framed Gallery, 2018, 16-26.

Lüsebrink, Hans-Jürgen. La conquête de l'espace public colonial. Prise de parole et formes de participation d'écrivains et d'intellectuels africains dans la presse à l'époque coloniale (1900-1960). Frankfurt am Main/London: IKo; Québec, Nota Bene, 2003.

Linyekula, Faustin. "Lubunga en res(eaux)." Studio Kabako. http://www.kabako.org/ Kisangani/Lubunga.html. 27 Apr. 2021.

Maître Gims. "Sapé comme jamais." Youtube, uploaded by GIMS, 19 Oct. 2015. https:// www.youtube.com/watch?v=4bPGxLxogvw\&start_radio=1\&list=RD4bPGxLxogvw. 25 Apr. 2021.

Mangeon, Anthony. Lumières noires, discours marrons. Indiscipline et transformation du savoir chez les écrivains noirs américains et africains: itinéraires croisés d'Alain Leroy 
Locke, V.Y. Mudimbe et leurs contemporains. 2004. University of Cergy-Pontoise, Paris, PhD dissertation.

Mignolo, Walter D., and Madina Tlostanova. "Theorizing from the Borders: Shifting to Geo- and Body-Politics of Knowledge." European Journal of Social Theory 9:2 (2006), $205^{-21 .}$

Mignolo, Walter D. The Darker Side of Western Modernity: Global Futures, Decolonial Options. Durham: Duke UP, 2011.

Mopila, Francisco-José. Memorias de un Congolés. Ensayo de auto-biografia. Madrid: Consejo Superior de Investigationes Cientificas-Instituto de Estudios Africanos, 1949.

Mouralis, Bernard. "Littératures africaines, Oral, Savoir." Semen 18 (2004). http://journal s.openedition.org/semen/2221. 25 Apr. 2021.

Mudimbe, V.Y., and Sam Okoth Opondo. "Explorations on Intellectual Ethnicity, Philosophy and Ethnological Reason." The Salon:Johannesburg Workshop in Theory and Criticism 10 (2015), 1-9. https://docplayer.net/147763398-The-johannesburg-salon-vo lume-ten-2015.html. 25 Apr. 2021.

Mudimbe, V.Y. The Idea of Africa. Bloomington: Indiana UP, 1994.

Mudimbe, V.Y. “'Reprendre': Enunciations \& Strategies in Contemporary African Arts.” In Africa explores: 2oth Century African Art. Eds. Susan Vogel and Ima Ebong. New York: Center for African Art; München: Prestel, 1991, 276-87.

Mudimbe-Boyi, Elisabeth. "Des traces littéraires haïtiennes au Congo." Continents manuscrits 15 (2020). Web. 25 Apr. 2021.

Mujila, Fiston Mwanza, and Sammy Baloji. Abattoir des rêves ou la faute à Bende, l'Aîné des Hommes, d'avoir boycotté la Création? Rome: Villa Medici, 2020. https://www .villamedici.it/fr/les-jeudis-de-la-villa/abattoir-des-re\%CC\%8ves-ou-la-faute-a-be nde-lai\%CC\%82ne-des-hommes-davoir-boycotte-la-creation/. 25 Apr. 2021.

Mujila, Fiston Mwanza. Tram 83. Paris: Éditions Métailié, 2014.

Mujila, Fiston Mwanza. Tram 83. Trans. Roland Glasser. Plymouth (UK): Jacaranda Books, 2015.

Mujila, Fiston Mwanza. La Danse du vilan. Paris: Éditions Métailié, 2020.

Newkirk, Pamela. The Astonishing Life of Ota Benga. New York: Amistad, 2015.

Ndala, Blaise. Dans le Ventre du Congo. Paris: Seuil, 2021.

Ndala, Blaise. Sans capote ni kalachnikov. Montréal: Mémoire d'Encrier, 2017.

Ndala, Blaise. J'irai danser sur la tombe de Senghor. La Roque d'Anthéron: Vents d' ailleurs, 2014.

Nkashama, Pius Ngandu. Le Pacte de Sang. Paris: L'Harmattan, 1984.

Nkashama, Pius Ngandu. Blood Pact. Trans. Heidi Melissa Demman. U.S.: Strategic Book Publishing \& Rights Agency LLC, 2019.

Nkashama, Pius Ngandu. Mon Grand Père et la Conquête de la paix. Paris: L' Harmattan, 2020 . 
Orsini, Francesca, and Laetitia Zecchini. "The Locations of (World) Literature: Perspectives from Africa and South Asia - Part I: Visions and Networks." Journal of World Literature 4:1 (2019), 1-12.

Orsini, Francesca. "Reading Together: Hindi, Urdu, and English Village Novels." In Indian Literature and the World. Eds. Rosella Ciocca and Neelam Srivastava. London: Palgrave Macmillan, 2017, 61-85.

O’Toole, Sean. "My True Country Is My Body." Features 183. 23 November 2016. https:// www.frieze.com/article/my-true-country-my-body. 25 Apr. 2021.

Rettova, Alena. "African Philosophy in Multiple Disguises." Institut für Wissenschaft und Kunst (IWK), lecture 11/06/2015. https://www.iwk.ac.at/events/alena-rettova-african -philosophy-in-multiple-disguises-2. 10 Jan. 2021.

Riva, Silvia. "From Cosmopolitanism to Planetary Metonymy and Back: Some Rhetorical Considerations in World Literature." Letteratura E Letterature 11, 2017, 95-117.

Riva, Silvia. “Global Congo." Continents Manuscrits 15 (2020). Web. 20 Apr. 2021.

Rivers Ndaliko, Cherie. Necessary Noise: Music, Film, and Charitable Imperialism in the East of Congo. Oxford: Oxford UP, 2016.

Saint-Moulin, Léon de. "La mondialisation dans la Commune de Ngaba à Kinshasa." Congo-Afrique 327 (1998), 419-43.

Sapiro, Gisèle, and Delia Ungureanu. "Pascale Casanova's World of Letters and Its Legacies: Introduction." Journal of World Literature 5:2 (2020), 159-68.

Seck, Abdourahmane. "Panser l'en-commun: un agenda décolonial pour l'Afrique Francophone." In Écrire l'Afrique-Monde. Eds. Felwine Sarr and Achille Mbembe. Paris, Dakar: Philippe Rey, Jimsaan, 2017, 309-39.

Shuílleabhaín, Míde Ní, "Inviting Marianne to Dance: Congolese Rumba Lingala as an Archive Against Monument." In Politics of African Anticolonial Archive. Eds. Shiera S. el-Malik and Isaac Kamola. London: Rowman \& Littlefield, 2017, 101-20.

Velsen, Vincent van. A Blueprint for Toads and Snakes: Curatorial Essay. Amsterdam: Framer Framed Gallery, 2018. https://framerframed.nl/wp-content/uploads/2018/ o6/ABFTAS-HANDOUT-DIGITAAL_C.pdf. 25 Apr. 2021.

Vuillard, Éric. Congo. Récit. Arles: Actes Sud, 2012.

West-Pavlov, Russell, ed. The Global South and Literature. Cambridge: Cambridge UP, 2018.

"Blacks to the future." Blacks to the future. http://blackstothefuture.com/en/about/. 25 Apr. 2021

"Lettres du continent." Institut français. https://www.institutfrancais.com/en/close-up/ lettre-du-continent-21-african-artists-on-the-public-health-crisis. 20 Apr. 2021.

"Observatoire de la langue française de l'Organisation internationale de la Francophonie." Organisation Internationale de la Francophonie, 2018. http://observatoire .francophonie.org/wp-content/uploads/2018/og/Francophones-Statistiques-par-p ays.pdf. 20 Nov. 2020 
"Pour une littérature-monde en français." Le Monde. 15 Mar. 2007. Web. 20 Apr. 2021.

"Tukooos." Afropop Worldwide. 20 Sep. 2017. https://afropop.org/articles/tokooos. 25 Apr. 2021. 10 Apr. 2021. 